\title{
Environmental Damage Impact on Economic Losses in Sulawesi-South Society
}

Solihin Matalatta ${ }^{1}$, Yusrab Ardianto ${ }^{1}$, Junaidin ${ }^{1}$, Abdul Karim ${ }^{1 *}$

${ }^{1}$ STIE AMKOP Makassar, South Sulawesi, Indonesia

DOI: $10.36348 /$ sjef.2021.v05i02.003 $\quad$ | Received: 29.01.2021 | Accepted: 15.02.2021 | Published: 17.02 .2021

*Corresponding author: Abdul Karim

\section{Abstract}

Losses for ecological disasters in South Sulawesi Province were recorded accumulated at IDR 8.03 trillion. The worst ecological disaster of floods and landslides in Luwu Regency, about 38 victims died, 13438 residents were displaced, 1986 hectares of rice, 505 hectares of corn, and 244 hectares of cocoa were damaged. The ecological disaster worth IDR 8 trillion, the flood disaster in Bantaeng Regency resulted in 2 deaths, 2333 houses damaged, 197 hectares of rice fields and plantations were submerged by water due to the flood. Loss of IDR 33 billion, stopping the seizure of people's living space, protecting farmers, fishermen, women, and indigenous peoples must be carried out by the provincial government of South Sulawesi. Apart from this, the government must also revoke mining permits that are not in accordance with the regulations, and stop involving colleagues in the state revenue expenditure budget and regional revenue expenditure budget projects that are ecologically damaging and not environmentally sound.

Keywords: Environmental, Economic, South Sulawesi.

Copyright (C) 2021 The Author(s): This is an open-access article distributed under the terms of the Creative Commons Attribution 4.0 International License (CC BY-NC 4.0) which permits unrestricted use, distribution, and reproduction in any medium for non-commercial use provided the original author and source are credited.

\section{INTRODUCTION}

Throughout 2020, material losses due to damage from the environmental impact, confiscation of space to the ecological disaster of South Sulawesi Province reached IDR 8.24 trillion [1]. This loss is the result of the impact of the space confiscation of around IDR 165.7 billion. This space grabbing is like the process of building a new port (Makassar New Port). There are 984 traditional fishermen who have suffered losses due to the construction of the new port [2].

The material losses felt by traditional fishermen during the construction of the Makassar New Port are divided into fishing fishermen who suffered losses of IDR 250 thousand per day with an accumulation of IDR 64.2 million [3]. Crab fishermen lost IDR 300 thousand per day with an accumulation of IDR 77.1 million, while women shellfish fishermen lost IDR 35 thousand per day with an accumulation of IDR 8.9 million from the total number of fishermen in the Makassar New Port development area [4]. Meanwhile, the loss of coastal communities and fishermen in Makassar City during the 257 days of the sea sand mining process is around IDR 54.9 billion.
Material loss from the impact of seizure of sea sand mining space by PT. Bokalis, there were 1043 fishermen on Kodingakreng Island and its surroundings. Arrow fishermen lose IDR 200 thousand per day, with an accumulation of IDR 51.4 million [5]. Bagan fishermen lose IDR 2 million per day with an accumulation of IDR 514 million. Fishing rods lose IDR 300 thousand per day with an accumulation of IDR 77.1 million. The net fishermen lost IDR 1.4 million with an accumulation of IDR 359.8 million. The total loss suffered by fishermen of Kodingareng Island Makassar during the 257 days of another sand dredging process is IDR 80.4 billion [6].

In addition to the seizure of space for the fishing community, there was also the seizure of space in East Luwu Regency, South Sulawesi Province for the Pamona and Pancakarsa indigenous peoples by PTPN XIV. A land area of six hectares from 500 hectares of cultivated oil palm is managed by PTPN XIV. In material terms, each hectare of agricultural land benefits IDR 600 million. It is recorded that 214 farmers are victims of land grabbing [7]. 
Currently, 506 hectares of acres have been taken over by the company under the auspices of the government for the expansion of oil palm plantations. The people of Panoma and Pancakarsa have lost IDR 30.3 billion. The land which is used as a right to cultivate by PTPN XIV is 814 hectares, obtained from the land of the Panoma indigenous people [8], which has an area of 938 hectares since 1960.

\section{LITERATURE REVIEW}

\section{Environmental problems based on the duties of the provincial government}

Since 2013, the regional environmental agency of South Sulawesi Province [9] has carried out a mapping of very chronic problems, including:

1) Watershed damage caused by various types of current land uses such as forest use, rice fields, fields, plantations, grasslands, shrubs, and other types that have an impact on the sustainability of several watersheds, such as the Jeneberang watershed, the Bila Watershed, and the Walanae Watershed [10]. The vegetation cover of the watershed is currently estimated at $70 \%$ of the total area, but on the other hand, flooding continues to occur in the area and the impact is even wider and the inundation time is longer [11]. This indicates that the land cover in the upstream watershed has been damaged as a result of forest encroachment activities [12].

2) Flood is a major problem that continues to occur and its intensity continues to increase which requires serious attention in South Sulawesi [13]. This is very unsettling for the community, especially those who live around the Jeneberang, Saddang, Bila, Walanae, Cendranae, and other large rivers with increasing flood discharge every year.

3) Sedimentation is one of the main environmental problems in South Sulawesi Province [14]. Where every year there is an increase in sedimentation in several main rivers in this area which is quite high.

4) Water pollution in South Sulawesi has recently become more significant, this is due to human activities that are carried out without paying attention to the surrounding environment. As we know that lakes, rivers, oceans, and groundwater are an important part of the human life cycle and are a part of the hydrological cycle [15]. Water pollution is caused by various things, including: first, organic waste such as sewage (sewage) causes an increase in oxygen demand for the water that receives it which leads to reduced oxygen which can have a severe impact on the entire ecosystem. Second, factory waste that flows into the river, which contains various kinds of pollutants such as organic matter, nutrients, and suspended solids [16].

5) Air pollution is a very important issue considering the increasing human activity which every day has the opportunity to create very high air pollution. We need to take this together by reducing the rate of air pollution that occurs in urban areas and industrialized areas that produce substances above normal limits [17]. Air pollutant gases include CO, $\mathrm{CO}_{2}, \mathrm{NO}, \mathrm{NO}_{2}, \mathrm{SO}, \mathrm{SO}_{2}$. The more motorized vehicles and industrial equipment that pollute the environment, the more severe the air pollution that occurs, the worse the air quality is due to the narrowing of green land or trees in an area, therefore there is a need for the participation of government, businessmen and the community to be able to solve the problem of air pollution in South Sulawesi [18].

6) Damage to coastal ecosystems, damage to mangrove forests in South Sulawesi [19] are caused by weaknesses in various factors, including policies on the utilization of coastal areas, policies on mangrove forest management, law enforcement, and coordination between sectors of related agencies in the utilization of coastal areas. Damage to coral reefs in South Sulawesi has caused a decline in fish population/production along the coast.

7) Currently, the problem of solid waste is an important issue that requires proper handling, where the consumption pattern of the community has not yet led to environmentally sound patterns so that the use of packaging in the form of paper, plastic bags, cans, and other materials is still high [20]. This causes an increase in the number of urban waste piles, but generally, this increase in number is not followed by adequate waste infrastructure and facilities so that untreated waste becomes a source of pollution [21].

8) Degradation of biodiversity, biodiversity in South Sulawesi needs to be preserved through protection and sustainable use as mandated in Law No. 5 of 1994 concerning Biodiversity. Biodiversity consists of components, genes, species, and ecosystems which are resources and services for human life [22].

9) Forest damage, forest conditions in South Sulawesi Province are experiencing increasing degradation due to shifting cultivation activities, illegal logging [23], excessive forest exploitation, and other people's activities in forest areas. We need to know that the damage to critical land forests in South Sulawesi covering an area of 682784.29 hectares consisting of 312827.74 hectares is outside the protected forest area [24].

\section{METHOD RESEARCH}

This research is a descriptive study designed to collect data, compile systematically, factually, and carefully with the aim of gathering information about current real conditions. This type of research can be used as an appropriate tool and is expected to provide a new meaning explaining the real conditions of the environment and causing material losses in Sulawesi Province in several districts. Descriptive research tends not to need to find or explain the relationship between relationships and test hypotheses with qualitative data derived from social variables collected in the form of words and pictures. 
Based on data, data collection, and data analysis process, this study uses mixed methods by combining qualitative and quantitative methods. The combined research method is a research method that combines quantitative and qualitative methods together to obtain more comprehensive, valid, realistic, and objective data. In the first stage, the researcher collected and analyzed quantitative data, which was then followed by the collection and analysis of qualitative data to strengthen the results of his research.

\section{RESULT AND DISCUSSION \\ Result}

The main pillar of development and the network of accelerated welfare nodes

The description of the current position of South Sulawesi becomes a reference and contributes significantly to the solution to Indonesia's fundamental problems. These fundamental problems are particularly in the realization of food security, independence, and sovereignty in which Indonesia still imports rice, salt, corn, and meat. South Sulawesi also plays a more important role in developing an ideal pattern of an embodiment of religious life and harmony between religious communities, in addition to being able to develop the system of national, state, and community life, especially in developing democracy, in a substance and context that is in accordance with the manner and character of South Sulawesi.

The Network Node is a description of the position of Sulawesi which increasingly positions itself as a center of growth and development outside Java, a center for goods and services, education relations, health relations, as well as land, sea, and air transportation. With such a position, South Sulawesi is increasingly able to synergize the progress of districts and cities and to synergize more with regional, national and international developments.

Table-1: The main pillars of development and the network of accelerated welfare nodes

\begin{tabular}{|c|c|c|c|}
\hline \multirow{2}{*}{ Purpose } & \multirow[t]{2}{*}{ Problem } & \multicolumn{2}{|l|}{ Factor } \\
\hline & & Weakness & Strength \\
\hline \multirow{4}{*}{$\begin{array}{l}\text { Improve the quality of } \\
\text { economic prosperity, social } \\
\text { welfare, and environmental } \\
\text { sustainability }\end{array}$} & $\begin{array}{l}\text { The increasing number of } \\
\text { development activities will } \\
\text { reduce the carrying capacity } \\
\text { and carrying capacity of the } \\
\text { environment and increase } \\
\text { environmental pollution }\end{array}$ & $\begin{array}{l}\text { The absence of } \\
\text { regional level } \\
\text { regulations regarding } \\
\text { environmental } \\
\text { conservation and } \\
\text { management }\end{array}$ & $\begin{array}{l}\text { Law Number 32/2009 } \\
\text { concerning Environmental } \\
\text { Protection and Management }\end{array}$ \\
\hline & $\begin{array}{l}\text { Public participation } \\
\text { awareness in environmental } \\
\text { conservation is not optimal }\end{array}$ & $\begin{array}{l}\text { Human resources are } \\
\text { still limited both in } \\
\text { quantity and quality }\end{array}$ & $\begin{array}{l}\text { Regional Regulation } \\
\text { No. 9/2009 concerning } \\
\text { regional spatial planning }\end{array}$ \\
\hline & $\begin{array}{l}\text { There is no synergy in } \\
\text { environmental management } \\
\text { between related sectors }\end{array}$ & \multirow{2}{*}{$\begin{array}{l}\text { Lack of facilities and } \\
\text { infrastructure for } \\
\text { environmental } \\
\text { management. }\end{array}$} & $\begin{array}{l}\text { Availability of regional } \\
\text { revenue and expenditure } \\
\text { budgets }\end{array}$ \\
\hline & $\begin{array}{l}\text { Limited resources, including } \\
\text { tools, human resources }\end{array}$ & & $\begin{array}{l}\text { Availability of an } \\
\text { accredited and registered } \\
\text { environmental laboratory }\end{array}$ \\
\hline
\end{tabular}

Primary data, 2021

South Sulawesi through the management of diversity in human, social, cultural, natural, physical, and financial capital so as to accelerate the realization of a just and sustainable economic prosperity, social welfare, and environmental sustainability. Agroindustry is growing rapidly as a continuation of the development of agribusiness, while the manufacturing and mining industries will contribute significantly to the structure of the economy. This condition is the final phase of the take-off era and is the beginning of economic maturity which has shown the formation of a significant middle class and civil society.

\section{Regional spatial planning and strategic environmental studies}

The spatial plan for the province of South Sulawesi for 2009-2029 has been ratified through the
Regional Regulation of the Province of South Sulawesi Number 9 of 2009. The general objective of spatial planning for the province is to organize the spatial planning for the South Sulawesi region including the coast and its small islands into transportation, industrial, and transportation hub. Trade, tourism, settlements, agriculture, sustainable food land, as well as to improve the environmental quality of watersheds, synergistically between sectors and between regions, participatory, democratic, fair, and balanced, in the national spatial planning system, which leads to a process of increasing welfare the people, especially the people of South Sulawesi in a sustainable manner.

Study of regional spatial planning along with inhibiting factors and driving the success of its handling, as in the following table: 
Table-2: Spatial plan for South Sulawesi Province

\begin{tabular}{|c|c|c|c|}
\hline \multirow[t]{2}{*}{ Spatial plans } & \multirow[t]{2}{*}{ Problem } & \multicolumn{2}{|l|}{ Factor } \\
\hline & & Weakness & Strength \\
\hline \multirow{3}{*}{$\begin{array}{l}\text { Rehabilitation and } \\
\text { development of } \\
\text { provincial strategic } \\
\text { areas from the point of } \\
\text { view of the importance } \\
\text { of environmental } \\
\text { functions and carrying } \\
\text { capacity }\end{array}$} & $\begin{array}{l}\text { The reduced carrying capacity, } \\
\text { function, and quality of the } \\
\text { environment due to environmental } \\
\text { pollution and damage }\end{array}$ & $\begin{array}{l}\text { There has not been a strategic } \\
\text { environmental study related } \\
\text { to the development of } \\
\text { provincial strategic areas }\end{array}$ & $\begin{array}{l}\text { Regional Regulation No. 9/2009 } \\
\text { concerning regional spatial } \\
\text { planning }\end{array}$ \\
\hline & $\begin{array}{l}\text { Increased damage to coastal areas } \\
\text { and their ecosystems }\end{array}$ & \multirow{2}{*}{$\begin{array}{l}\text { Weak supervision and law } \\
\text { enforcement regarding the } \\
\text { suitability of zoning areas }\end{array}$} & \multirow{2}{*}{$\begin{array}{l}\text { South Sulawesi Governor } \\
\text { Regulation No. 17/2013 } \\
\text { concerning space utilization } \\
\text { permits in Indonesia's integrated } \\
\text { central business district }\end{array}$} \\
\hline & $\begin{array}{l}\text { There is no planning related to the } \\
\text { revitalization of the area and } \\
\text { improving the quality of the area }\end{array}$ & & \\
\hline
\end{tabular}

Primary data, 2021

The main program formulated in the regional spatial plan of South Sulawesi Province is related to the environment, namely the rehabilitation and development of provincial strategic areas from the point of view of the interests of the function and carrying capacity of the environment, this main program consists of two sub-programs, namely: First, rehabilitation/revitalization of the area, and second, development/improvement of area quality.

Based on the main program, the Regional Environmental Agency of South Sulawesi Province presents the driving and inhibiting factors for services that can affect the achievement of the regional spatial planning program targets.

\section{DISCUSSION}

During the Covid-19 Pandemic currently hitting all countries in the world, the practices of environmental crimes committed by corporations in South Sulawesi Province are also continuing and ignoring the global situation. Economic investment is prioritized so that it causes community rights to be neglected, women's rights are castrated, eliminated and environmental crimes occur in several areas in South Sulawesi Province. Sea sand mining by the Queen of the Netherlands Ship owned by PT. Royal Boskalis in Sangkarrang Waters, Makassar City. The fishermen also urged the government to revoke the permit of PT Banteng Laut Indonesia as the holder of the mining business license and move the mine site to a distance of 45 miles from the fishing area.

In Makassar waters, there are 20 companies that have concessions with the South Sulawesi Provincial Government. The total permit area reaches 17110.03 hectares. The companies holding these concessions are located in Takalar District. Currently, sand dredging is still ongoing at PT. Indonesian Sea Bull. Previously PT. Alefu Karya Makmur. The distance between Copong Lompo, the sand dredging site, from Kodingareng Island is about 10 miles. This distance can be reached by a 10 PK engine fishing boat, about 45 minutes. Cruising fishermen looking for fish not limited to administrative areas. These areas are a source of fish and investment in fishermen's life. In this zone, the best fish gather, from mackerel to skipjack.
2020 is a bad period for the environment in Indonesia, especially in South Sulawesi Province. There is a denial of the correlation between the destruction of the natural environment and the global outbreak of a pandemic. The natural resource-based economic acceleration is considered as the answer to the crisis caused by the pandemic. Environmental defenders actually come under pressure from the authorities in the form of criminalization and violence. It is predicted that the authorities will continue to deepen activities to accelerate resource extraction rather than reduce it to support natural resource conservation efforts.

The absence of changes in the character of the government in viewing and managing the environment exacerbates a sense of pessimism that in 2021 the environment and the lives of its guardians (rural communities, fishermen, indigenous peoples, and environmental activists) will be better. The final policy through the Ciptakarya Law is the most effective form and way of all investment projects and large-scale projects made by the government that will not be hindered, either by previous regulations or from tenure issues, customary issues, or land cultivation by farmers.

\section{CONCLUSION}

The conditions experienced by the global community related to the Covid-19 pandemic are an important and valuable lesson. The number of natural disasters that occurred in Indonesia in early 2021, as an ecological impact, did not get serious attention from all government-level institutions. Economic income only benefits the corporation or certain groups of the government to exploit the environment. As a result of this action, the people who were far more numerous suffered countless losses. South Sulawesi is a province in Indonesia that has also become a regular floodplain every year and there has never been a concrete solution from the government. This happens because the green open space, the less the volume.

\section{REFERENCES}

1. Karim, A. (2020). Improvement of Rural Economy Natural Movements Supporting Urban Economic Growth in Global Pandemic Period.

2. Azmanajaya, E., Paulus, C. A., \& Paranoan, N. (2020, February). The Sustainability index of the provision 
of clean water treatment plants (IPAB) in supporting SDG 2030 programs for the availability and management of sustainable clean water in Soppeng Regency, South Sulawesi Province, Indonesia. In IOP Conf. Series: Journal of Physics: Conf. Series (Vol. 1464).

3. Nurdin, N. H., Hamson, Z., \& Fatimah, S. (2019, March). Effectiveness of Industrial Community Development Control with an Environmental Insight in South Sulawesi Province. In First International Conference on Materials Engineering and Management-Management Section (ICMEMm 2018). Atlantis Press.

4. Syahruddin. \& Karim, A. ((2020)b). The Role of Cooperatives in Economic Growth in Makassar City during the Covid-19 Pandemic. International Journal of Innovative Science and Research Technology. Volume 5(10), pp. 334-337, October - 2020.

5. Karim, A. (2020). Indonesia's Economic Revival behind the Lockdwon of 59 Countries. International Journal of Scientific \& Engineering Research Volume, 11, 1385-1388.

6. Rum, M., \& Kusumawardani, A. (2020). Industrial Growth and Environmental Resource toward the Tax Potential: A Case Study in South Sulawesi Province. The Journal of Asian Finance, Economics and Business (JAFEB), 7(10), 201-210.

7. Wekke, I. S., Desi, N., \& Lubis, M. A. (2019). Islamic Students, Environmental Development and Parnertship: Study on Association of Islamic Students in Indonesia.

8. Lechner, A. M., Devi, B., Schleger, A., Brown, G., McKenna, P., Ali, S. H., \& Rogers, P. (2017). A socio-ecological approach to GIS least-cost modelling for regional mining infrastructure planning: a case study from South-East sulawesi, Indonesia. Resources, 6(1), 7.

9. DeVantier, L., Alcala, A., \& Wilkinson, C. (2004). The Sulu-Sulawesi Sea: environmental and socioeconomic status, future prognosis and ameliorative policy options. AMBIO: A Journal of the Human Environment, 33(1), 88-97.

10. Malik, A., Fensholt, R., \& Mertz, O. (2015). Economic valuation of mangroves for comparison with commercial aquaculture in South Sulawesi, Indonesia. Forests, 6(9), 3028-3044.

11. Surya, B., Saleh, H., Suriani, S., Sakti, H. H., Hadijah, H., \& Idris, M. (2020). Environmental pollution control and sustainability management of slum settlements in Makassar City, South Sulawesi, Indonesia. Land, 9(9), 279.

12. Maddatuang, B., Sabara, Z., Wekke, I. S., \& Karim, A. (2020). Langkah Mewujudkan Insan Cita Pandangan Lintas Disiplin. Penerbit Qiara Media.

13. Karim, A. (2020). The Agricultural Sector is a Pillar of Economic Growth during the Covid-19 Pandemic After the Ratification of the Omnibus Law Job Creation in Indonesia.
14. La Ode, M. A., Iba, W., Ingram, B. A., Gooley, G. J., $\&$ de Silva, S. S. (2015). Mariculture in SE Sulawesi, Indonesia: Culture practices and the socio economic aspects of the major commodities. Ocean \& Coastal Management, 116, 44-57.

15. Desi, N., Alam, M., Rifdan, L., \& Pertiwi, N. (2017). Environmental Education Training Model to Improve Knowledge and Attitudes on the Friendly Environment of Community Organizations Members in Makassar. Research Journal of Applied Sciences, 12(2), 125-130.

16. Mattalatta, S. (2019). Pengaruh Kepemimpinan Situasional Terhadap Kepuasan Kerja, Organizational Citizenship Behavior Dan Kinerja Karyawan Pada Perusahaan Keluarga (Studi Kasus Pada Pt. Putra Karella Group). MANDAR: Management Development and Applied Research Journal, 1(2), 3543.

17. Suyuti, Y. A., Kitta, I., \& Akil, Y. S. (2017). The impact of the operation planning of power plants for environmental emissions in south sulawesi. ARPN J. Eng. Appl. Sci, 12(11), 3440-3444.

18. Zamroni, A., \& YAMAO, M. (2011). Assessment of the Socio-Economic Impact of the Small-Scale Natural Resources Management Program (SNRM) in Indonesia Case Study in Two Fishing Communities of South Sulawesi. Journal of Regional Fisheries, 52(1), 89-109.

19. Sabban, Y. A., \& Masyadi, M. (2020). Effect of work discipline, leadership style and training on employee performance in rsud haji makassar. Manajemen Bisnis, 10(2).

20. Halim, M. R., Mattalatta, S., \& Junaidin, J. (2020). Pengaruh penerapan manajemen waktu terhadap kinerja pegawai pada badan pengelola keuangan daerah kabupaten pangkep. SEIKO: Journal of Management \& Business, 2(2), 182-188.

21. Ali, S. A., Anshary, H., \& Tahya, A. M. (2017). Environmental parameters and specific growth of Kappaphycus alvarezii in Saugi Island, South Sulawesi Province, Indonesia. Aquaculture, Aquarium, Conservation \& Legislation, 10(4), 698702.

22. Rafiuddin, R., Alam, A. S., Muslimin, M., Rosmaniar, R., \& Aminah, S. (2021). Environmental Friendly Technology Innovation Based on Pure Organic Fertilizer on Arabica Coffee Commodities in Toraja Coffee Plantation, South Sulawesi Province. AECON, 292-298.

23. Atkinson, A. (1998). Developments in Urban Environmental Planning and Management in Indonesia: The Secondary Cities of Sulawesi. University College, Development Planning Unit.

24. Seeberg-Elverfeldt, C., Schwarze, S., \& Zeller, M. (2008). Payments for environmental services: incentives through carbon sequestration compensation for cocoa-based agroforestry systems in Central Sulawesi, Indonesia. 